\title{
sciendo
}

\section{Big 4 and audit fees in the context of adopting International Financial Reporting Standards}

\author{
Marta TACHE \\ The Bucharest University of Economic Studies, Bucharest, Romania \\ tache.marta@yahoo.com
}

\begin{abstract}
The main purpose of this article is to determine the impact that Big 4 companies have had after the adoption of IFRS became mandatory and if the level of the fees related to the audit services registered a significant increase. Thus, after a thorough research of the specialized studies, we analyzed the impact of financial reporting according to the International Financial Reporting Standards, determining how the audit fees were influenced and which was the impact of the largest companies targeted in this study. In order to determine the number of companies audited by Big 4, we analyzed all the companies listed on Bucharest Stock Exchange, during the period 2010-2018, which trade premium shares. It is obvious that the financial reporting according to the International Financial Reporting Standards increases the number of companies audited by Big 4, although there has audit fees with higher values. In the following, we will analyze the changes that have occurred in the audit market of Romania.
\end{abstract}

Keywords: IFRS, Big 4, audit fees, financial reporting, accounting

\section{Introduction}

As Ball (2006) stated, accounting is the direct result of modeling economic and political factors, which led intrinsically to the harmonization of accounting standards. The private organization, the International Accounting Standards Board (IASB), was established in 1973 in London. It issued set of standards that are used to prepare financial statements: IASs (International Accounting Standards) were issued by the IASB until the end of 2001 and IFRSs (International Financial Reporting Standards). Currently, when we use the term IFRS, we refer to the set of rules (IAS / IFRS). The adoption of IFRS, at European Union level, has increased the credibility of the IASB body worldwide (Brown, 2013). The number of countries adopting IFRS has increased by 175 and is constantly increasing.

Moreover, globalization is the proper word that characterizes the 21st century, which leads intrinsically to a global set of standards, given that the number of multinationals has increased lately. As for the direct impact that Big 4 companies have on the global convergence of accounting and auditing standards, those in charge of Big 4 have always expressed their desire for a single global set of high quality standards. Financial reporting according to IFRS has led to a transition involving: a re-qualification of the auditors, a total restructuring at the level of software / technological platforms, specialized training for those who use the financial statements and not least, the existence of the regulatory systems aligned for the IFRS ( Tomasz Janowski).

\section{Literature review}

On a global level, the adoption of International Financial Reporting Standards (IFRS) has led to an increase in empirical research to improve the quality of financial reports, by systematically increasing value (Chalmers et al., 2012). Several empirical reviews have summarized the 
specialized literature referring to financial reporting under IFRS, but its effects on the audit market have not been deepened in our country. Finally, we identify several studies that specifically focus on auditor choice and compliance with IFRS (e.g., Hodgdon et al., 2009; Ebrahim, 2014) and other empirical work that generally examines the determinants of IFRS compliance, which is a testing variable (eg, Glaum et al., 2013). In addition to the other studies, regarding the adoption of IFRS on the quality of financial reports, another stream of research focuses on audit fees and how they have influenced Big 4 audit market firms.

On the level of the European Union, Pope and McLeavy (2011) analyzed the mandatory adoption of IFRS, in the light of the INTACCT project (European Revolution of IFRS: Conformity, consequences and political lessons). It was concluded that the effects of the adoption of IFRS will never be uniform, due to the different incentives of the developers but also of the application method.

On the level of our country, Romania, this aspect has been marked since 2012, when the adoption of International Financial Reporting Standards became mandatory, which implies a continuous economic and financial transformation. The term already known as "Big 4" was first used at the beginning of the 19th century, to designate the largest companies. The origin of these terms "Big 4"and "audit" were first encountered in the Anglo-Saxon countries. The connection between them is given by the international analysis of audit services. As Zeff states, in 2003, these firms (Deloitte Touche Tohmatsu, Ernst \& Young, KPMG and PricewaterhouseCoopers) are considered the engine of profitability and internationalization of audit and accounting services worldwide. Since 1970, customer expectations have increased with the competitiveness which exists on the audit market. This is the real reason why the auditors were forced not only to deliver accounting figures, but also new possibilities for meeting the inherent risk. These companies have, over time, changed their primary ethical objectives into commercial objectives. This shows that the audit services and consulting services were initially found separately, based on the following relation: the success of the audited firm proves the success of the consulting firm. The traditional role of large companies, as Tokar states, in 2005, is to provide guidance in the application of standards and to develop the same interpretation of the issues raised by IFRS. The first obstacle to a unanimous interpretation is given by a number of factors that differ from country to country. The Big 4 dictionary is: "one interpretation, one name".

The number of countries adopting IFRS is increasing because this financial reporting implies a number of advantages, namely: it increases the level of investments at international level and the ability of foreign investors to make economic decisions, significantly reduces managerial discretion (In Continental Europe, the accounting system allowed the manipulation of results accounting, efficiency of reflecting financial gains / losses (Ball, 2014), the ability of investors to make informed decisions, eliminating any confusion regarding the measurement of the entities performance, reducing the costs regarding the preparation / processing of accounting information, more efficient allocation of financial resources, increases the comparability of the financial statements, the benefits resulting from the adoption of IFRS are higher than the costs of implementing this paradigm, the commitment of managers increases because the degree of evaluation increases, the use of certain recognition / measurement criteria that it effects the economic reality, information materialized in accounting notes and the free access to the specific competences of accounting standardization (Brown, 2013).

In order to be able to write about the audit fees, we must start from the expenses underlying the transactions of an entity. Agency Theory (Agency Theory) highlights the immanent chain of contracts between associates / shareholders and agents (managers who are required to control all the resources within an entity) (Jensen and Meckling, 1976; Adams, 1994). This theory postulates 
the general idea that the shareholders / shareholders do not have access to all the information when the managers have to make certain decisions. The informational asymmetry that emerges from this theory can be a moral hazard, when managers act only for the purpose of maximizing their own wealth and not for the purpose of the company they work for (Mohammad A., 2011).

There is the possibility of a decrease in the establishment of monitoring processes from the point of view of the managers, which affect the working conditions of the audit companies (Hudson, 2014). In this context, the Theory of the Agency postulates that the managers tend to favor the interests of the shareholders to the detriment of the creditors, which may include restrictions in the contracts carried out (Watson et al., 2002), which lead to the distorted increase of the agency's costs. This is the moment where the auditors defend the interests of the shareholders / creditors impartially, verifying the internal controls, the risk and the financial reporting of the management.

For the first time, this aspect was observed by Jensen and Meckling as follows: "the existence and size of agency costs depend on the nature of the costs monitored by the agent (manager)". The audit companies having the obligation to control the financial statements and the management behavior attest to the decrease of the expenses related to the audit services. In 2011, in a specialized journal, Leventis stated that: "audit costs are the most measurable and direct costs of the agency and reducing audit costs reveals reducing agency costs." It is quite obvious the conclusion that the audit firms make bigger checks when there are problems, which increases the number of hours worked, leading to an increased level of expenses. Another advantage of large firms compared to small firms is that they have a rather sophisticated accounting system, thus having an advantage given by internal audit, which immanently reduces the total level of expenses related to audit services. For example, in France, adopting IFRS for the first time increased the quality of financial statements (Cormier et al., 2009). In another study, profit management increased after adopting IFRS in France (Jeanjean and Stolowy, 2008). Therefore, there are some studies that prove that these expenses related to audit services increase with the adoption of IFRS (Vieru \& Schadewitz, 2010).

\section{The relationship between financial reporting according to IFRS and audit fees}

The main objective of the financial reports is to provide information for the internal and external users of the financial statements. The audit report represents an assurance for potential capital providers / investors, lending decisions but also the systematic allocation of resources to increase the overall efficiency of the capital market. Thus, the desire for convergence is supported by many arguments in the context of a common financial language. In the future, when the scope of IFRS will expand in Romania, many investors would benefit from common information systems and similar results.

The specialized literature makes the appearance of the request for audit services on the basis of four basic theories:

1. Policeman Theory

2. The Lending Credibility Theory

3. The Theory of Inspired Confidence

4. Theory of Agency (Hayes et al., 2005).

The necessity for comparability and evaluating the performance of financial statements has increased gradually, in recent years, for some public interest entities and the reporting framework that provides comparable information is represented by the International Financial Reporting Standards.In order to report stature, listed companies are obliged to use IFRS, while most Romanian companies use RAS. For foreign investors, companies are obliged to use both standards, 
and can report to the principal company.

There is a number of differences in form (presentation of financial statements) but also in substance (the content of financial statements that materialize in a different result). Therefore, until the Romanian standards become similar to the international standards, we will have totally different results, regarding: the deferred tax (term met in the financial statements according to IFRS, but which does not exist in the financial statements according to the RAS), the evaluation of the real estate investments. (notion that is accounted to the fair value according to IFRS respectively, it is registered for revaluation reserves according to RAS), goodwill (item not depreciated under IFRS, respectively depreciation according to RAS), difference between functional currency (IFRS) and presentation currency (RAS) and the two standards, IFRS 15 and IFRS 16 have brought considerable changes, changes that are not found in the Romanian accounting. IFRS 15 - Revenue recognition has brought considerable changes, especially in telecommunications, real estate investments and software development. According to International Standards, revenue recognition goes from the transfer of risks / benefits to the transfer of control. IFRS 16 - Leasing standard recognizes the right of use as an element of the respective leasing asset, as a debt, with no operational / financial leasing distinction. Regarding the standard IFRS 9 Financial Instruments, it brings significant changes to the level of financial results.

Audit services play a critical role in applying the new reporting standards, especially on implementation costs (Loukil, 2016). Since the financial reporting according to the International Financial Reporting Standards became mandatory, the audit costs have undergone considerable changes. These fees have increased because the new reporting model requires a greater effort, which automatically leads to an increase. The audit is the control mechanism of the company and its main purpose is to reduce agency costs. It has always been seen as: "a politically neutral technique of auditing accounts" (Flint, 1988 cited in Klarskov Jeppesen, 1998: 518)

The relationship between audit expenses and financial reporting according to International Financial Reporting Standards is based on the adoption of IFRS which involves an additional effort from the audit firms that must verify additional information: footnotes, asset / debt assessment but also managerial forecasts (DeGeorge et al., 2013)and the adoption of IFRS increases professional judgment (KPMG, 2007; Diehl, 2010) because these principles are based on fair value, which can significantly increase the errors encountered and the risk encountered can lead to a significant distortion (DeGeorge et al., 2013). Regarding the relationship between the audit expenses that record abnormal values and the discretionary power during the post IFRS period, Jung in 2016, attested that there exists a positive correlation. Moreover, the expenses related to the audit services are based on the following independent variables: total assets, total number of employees, stocks, liquidities, leverage, loss / profit of the company, rate of return on assets, increase of sales, audit firm, audit opinion and changing the audit firm (Boone et al., 2010; Choi et al., 2010; Reichelt and Wang, 2010; Lopez and Peters, 2012; Asthana and Boone, 2012).

The exaggerated dimension of audit spending is based on the following theories:

- The theory of economic ties - this theory emphasizes that the independence of the audit can only be determined if there is an economic commitment, which can influence the quality of the audit. In this case, the client has to pay higher audit expenses, instead having a managerial discretion in their financial statements or annual reports (Choi et all, 2010).

- The theory of audit effort - this theory shows that an exaggerated increase in these expenses does not automatically lead to an increase in the quality of the audit services. (Eshleman si Guo, 2014).

On the other hand, the Theory of the Agency attests that the existing monitoring mechanisms align the interests of the two involved parties (managers and shareholders), in order to eliminate the inherent conflict of interests but also to eliminate an opportunistic manager's 
behavior (Alzoubi, 2016). This monitoring is given by the audit companies that solve the existing divergences at the management and shareholder level, manage the behavior of the opportunistic managers and even reduce the existing information asymmetry. The information asymmetry must be reduced by the audit firms, which must detect all the differences between the annual financial statements and the current data. The work of the auditor, which materializes in the audit opinion, must be a guarantee for foreign investors. The relationship between financial audit and the quality of audit services has changed with the adoption of IFRS. Therefore, the fair value that results from convergence with IFRS increases discretionary power in making one's own decisions (Hamberg et al., 2011).

These audit expenses are based on audit effort and risk, factors that are influenced by audit firms (Choi et al., 2008). As an example, in South Korea, audit costs may be affected in some cases by KAP discounts when the audit firm observes a rather low audit risk value. At the same time, the fierce competition of KAP and the rates related to the audit services, can lead to compensations regarding the audit expenses, taking into account the effort but also the increased risk of audit leading to the increase of the quality of the audit services (Park, 2012). Current research shows that there is a correlation between audit costs and the size of the audited firm (Simunic, 1980, Walace, 1984, Fleischer and Goettsche, 2012, Fung et al., 2012). Other specialized studies show that these expenses are inversely proportional to the size of the audited firm (Simunic, 1980, Wallace, 1984).

\section{Methodology}

The present analysis is based on official data published by Bucharest Stock Exchage, Eurostat, Transparency International and official site of Big 4 (Delloitte, E\&Y, KPMG \& PWC). The database is for the entire period 2010- 2018, which also contains the trasition year, registered for 24 companies from Romania, audited by Big 4/ Non Big 4 firms. The next variables used in our analysis are:

-Turnover (CA) divide the number of employees who leave each year by the average number of employees on the payroll and then multiply by 100 .

-Profit / loss (CPP) determine the net income (subtract the total expenses from the revenue), and divide the net income by the revenue. Then, multiply the result by 100 to arrive at a percentage.

- The average number of employees (NA) represents the number of employees employed with individual employment contracts, paid by the company for a normal average working time, during the reference period.It is determined that the simple arithmetic mean calculated by dividing the sum of the daily number of employees from the reference period, including weekly rest days, legal holidays and other non-working days, to the total number of calendar days.

Without trying or generalizing, someone can accept the idea that, in most statistical processing, someone can keep and take over for a hypothesis verification of the researchers.

The comparison of the average values accompanied by the Romanian market takes into account the correct distribution. It is important to know if they can be dispersed about can be considered equal or not. This is decided using the test F, based on theoretical distribution F (Fisher - Snedecor) (D. Jula, 2017).

Test hypotheses are close to unilateral bilateral and top tips.

Bilateral test: $H_{0}: \sigma_{1}^{2}=\sigma_{1}^{2} ; H_{1}: \sigma_{1}^{2} \neq \sigma_{1}^{2}$

One-sided tests: $H_{0}: \sigma_{1}^{2}=\sigma_{1}^{2} ; H_{1}: \sigma_{1}^{2}<\sigma_{1}^{2}$ sau $H_{1}: \sigma_{1}^{2}>\sigma_{1}^{2}$

When the null hypothesis is true, then the statistics $F^{*}=\frac{s_{1}^{2}}{S_{2}^{2}}$ are distributed $\mathrm{F}$ with $v_{1}=n_{1}-1$ and $v_{2}=n_{2}-1$, - the degree of freedom, when it can be used in tables values for $\mathrm{F}\left(v_{1} ; v_{2}\right)$ for determining critical probabilities. 
Table 1. Map of Europe for CPI

\begin{tabular}{|c|c|c|c|c|c|c|c|c|c|c|}
\hline & & 2010 & 2011 & 2012 & 2013 & 2014 & 2015 & 2016 & 2017 & 2018 \\
\hline $\begin{array}{l}\text { Crt. } \\
\text { No. }\end{array}$ & Company & Auditor & Auditor & Auditor & Auditor & Auditor & Auditor & Auditor & Auditor & Auditor \\
\hline 1 & $\begin{array}{l}\text { BRD-Groupe } \\
\text { Societe Generale } \\
\text { S.A. }\end{array}$ & Deloitte & Deloitte & Deloitte & Deloitte & Deloitte & Deloitte & EY & EY & EY \\
\hline 2 & $\begin{array}{l}\text { S.N. } \\
\text { Nuclearelectrica } \\
\text { S.A. }\end{array}$ & KPMG & KPMG & KPMG & KPMG & $\begin{array}{l}\text { Baker } \\
\text { Tilly }\end{array}$ & $\begin{array}{l}\text { Baker } \\
\text { Tilly }\end{array}$ & $\begin{array}{l}\text { Baker } \\
\text { Tilly } \\
\text { Klitou } \\
\text { and } \\
\text { Partner } \\
\text { s SRL } \\
\end{array}$ & Mazars & Mazars \\
\hline 3 & $\begin{array}{l}\text { S.N.G.N. ROMGAZ } \\
\text { S.A. }\end{array}$ & & & Deloitte & Deloitte & Deloitte & Deloitte & Deloitte & Deloitte & Deloitte \\
\hline 4 & CONPET SA & $\begin{array}{l}\text { SC } \\
\text { Fiscal } \\
\text { Consult } \\
\text { SRL }\end{array}$ & KPMG & KPMG & KPMG & KPMG & KPMG & BDO & BDO & BDO \\
\hline 5 & $\begin{array}{l}\text { Fondul } \\
\text { Proprietatea }\end{array}$ & Deloitte & Deloitte & Deloitte & Deloitte & BDO & Deloitte & Deloitte & Deloitte & Deloitte \\
\hline 6 & SIF Muntenia S.A. & KPMG & KPMG & KPMG & KPMG & KPMG & KPMG & KPMG & KPMG & KPMG \\
\hline 7 & $\begin{array}{l}\text { S.N.T.G.N. } \\
\text { TRANSGAZ S.A. }\end{array}$ & PWC & PWC & PWC & PWC & PWC & Deloitte & Deloitte & Deloitte & Deloitte \\
\hline 8 & $\begin{array}{l}\text { C.N.T.E.E. } \\
\text { TRANSELECTRIC } \\
\text { A }\end{array}$ & KPMG & KPMG & KPMG & KPMG & Deloitte & Deloitte & Deloitte & Deloitte & Deloitte \\
\hline 9 & $\begin{array}{l}\text { Societatea } \\
\text { Energetica } \\
\text { Electrica S.A. }\end{array}$ & KPMG & KPMG & KPMG & KPMG & KPMG & KPMG & KPMG & KPMG & KPMG \\
\hline 10 & $\begin{array}{l}\text { SIF } \\
\text { TRANSILVANIA } \\
\text { S.A }\end{array}$ & & & $\begin{array}{l}\text { SC } \\
\text { Nicolis } \\
\text { SRL }\end{array}$ & & PWC & & Deloitte & Deloitte & Deloitte \\
\hline 11 & $\begin{array}{l}\text { Banca } \\
\text { Transilvania S.A }\end{array}$ & KPMG & & $\begin{array}{l}\text { BT } \\
\text { Securiti } \\
\text { es SA }\end{array}$ & KPMG & KPMG & KPMG & PWC & PWC & PWC \\
\hline 12 & OMV Petrom & Deloitte & EY & EY & EY & EY & EY & EY & EY & EY \\
\hline 13 & Med Life & & & & Deloitte & Deloitte & Deloitte & Deloitte & Deloitte & Deloitte \\
\hline 14 & $\begin{array}{l}\text { SIF Banat Crisana } \\
\text { SA }\end{array}$ & & KPMG & KPMG & KPMG & KPMG & KPMG & PWC & PWC & PWC \\
\hline 15 & SIF Oltenia SA & $\begin{array}{l}\text { JPA } \\
\text { Audit \& } \\
\text { Consult } \\
\text { anta } \\
\text { SRL }\end{array}$ & $\begin{array}{l}\text { PA } \\
\text { Audit \& } \\
\text { Consult } \\
\text { anta } \\
\text { SRL }\end{array}$ & $\begin{array}{l}\text { PA } \\
\text { Audit \& } \\
\text { Consult } \\
\text { anta } \\
\text { SRL }\end{array}$ & $\begin{array}{l}\text { PA } \\
\text { Audit \& } \\
\text { Consult } \\
\text { anta } \\
\text { SRL }\end{array}$ & $\begin{array}{l}\text { JPA } \\
\text { Audit \& } \\
\text { Consult } \\
\text { anta } \\
\text { SRL }\end{array}$ & $\begin{array}{l}\text { PAA } \\
\text { Audit \& } \\
\text { Consult } \\
\text { anta } \\
\text { SRL }\end{array}$ & $\begin{array}{l}\text { PA } \\
\text { Audit \& } \\
\text { Consult } \\
\text { anta } \\
\text { SRL }\end{array}$ & $\begin{array}{l}\text { PA } \\
\text { Audit \& } \\
\text { Consult } \\
\text { anta } \\
\text { SRL }\end{array}$ & $\begin{array}{l}\text { JPA } \\
\text { Audit \& } \\
\text { Consult } \\
\text { anta } \\
\text { SRL }\end{array}$ \\
\hline 16 & $\begin{array}{l}\text { SPHERE } \\
\text { FRANCHISE } \\
\text { GROUP }\end{array}$ & & & & & & & EY & EY & EY \\
\hline 17 & ALRO S.A & Deloitte & Deloitte & Deloitte & EY & $E Y$ & EY & EY & EY & $\mathrm{EY}$ \\
\hline 18 & $\begin{array}{l}\text { SSIF BRK } \\
\text { Financial Group } \\
\text { S.A }\end{array}$ & & & & & & & Deloitte & Deloitte & Deloitte \\
\hline 19 & BIOFARM SA & $\mathrm{BDO}$ & BDO & BDO & BDO & BDO & KPMG & BDO & BDO & BDO \\
\hline 20 & ELECTROMAGNE & & & Audit & Audit & Audit & Audit & Deloitte & Deloitte & Deloitte \\
\hline
\end{tabular}




\begin{tabular}{|c|c|c|c|c|c|c|c|c|c|c|}
\hline & & 2010 & 2011 & 2012 & 2013 & 2014 & 2015 & 2016 & 2017 & 2018 \\
\hline $\begin{array}{l}\text { Crt. } \\
\text { No. }\end{array}$ & Company & Auditor & Auditor & Auditor & Auditor & Auditor & Auditor & Auditor & Auditor & Auditor \\
\hline & TICA S.A & & & $\begin{array}{l}\text { Expert } \\
\text { SRL }\end{array}$ & $\begin{array}{l}\text { Expert } \\
\text { SRL }\end{array}$ & $\begin{array}{l}\text { Expert } \\
\text { SRL }\end{array}$ & $\begin{array}{l}\text { Expert } \\
\text { SRL }\end{array}$ & & & \\
\hline 21 & Antibiotice S.A & BDO & BDO & BDO & $\mathrm{BDO}$ & $\mathrm{BDO}$ & BDO & $\mathrm{BDO}$ & SOCECC & SOCECC \\
\hline 22 & PATRIA BANK & EY & EY & KPMG & KPMG & Deloitte & Deloitte & Deloitte & PWC & PWC \\
\hline 23 & $\begin{array}{l}\text { IMPACT } \\
\text { DEVELOPER\&CO } \\
\text { NTRACTOR S.A }\end{array}$ & $\begin{array}{l}\text { Scot } \\
\text { \&Comp } \\
\text { any } \\
\text { Consult } \\
\text { ing }\end{array}$ & $\begin{array}{l}\text { RSM } \\
\text { Scot }\end{array}$ & $\begin{array}{l}\text { RMS } \\
\text { Scot }\end{array}$ & KPMG & KPMG & Deloitte & Deloitte & Deloitte & Deloitte \\
\hline 24 & SIF Moldova S.A & Deloitte & loit & te & eloit & elc & eloit & eloitte & loitte & eloi \\
\hline
\end{tabular}

Source: Own projection, usind Excel-Microsoft Office

In the transition year, the highest percentage of companies audited by Non Big 4 was registered compared to the analyzed period 2010-2018.

Table 2. Correlation matrix

\begin{tabular}{lrrr}
\hline & Profit/Loss & Turnover & Number of employees \\
\hline Profit/Loss & 1 & & \\
Turnover & 0,618119871 & 1 & \\
$\begin{array}{l}\text { Number of } \\
\text { employees }\end{array}$ & $-0,111998103$ & $-0,082707121$ & \\
\hline
\end{tabular}

Source: Own projection, usind SPSS

Thus, from the correlation matrix we can see that there is a direct link of average intensity, 0.618 , between the turnover of each company and its profit and two other inverse links of low intensity, -0.112 between the number of employees and the profit of the companies and respectively, -0.082 , the number of employees and the turnover of each company, all of which show that the turnover of a company on the Big 4 market correlates with the high level of audit fees.

Table 3. Model validity (ANOVA: Single Factor for the period 2010-2018)

Anova: Single Factor

SUMMARY

\begin{tabular}{lrrll}
\hline \multicolumn{1}{c}{ Groups } & Count & \multicolumn{1}{c}{ Sum } & Average & Variance \\
\hline EY & 9 & 22 & 2,444444444 & 1,527777778 \\
Deloitte & 9 & 65 & 7,222222222 & 7,4444444444 \\
KPMG & 9 & 44 & 4,888888889 & 7,111111111 \\
PWC & 9 & 14 & 1,555555556 & 1,027777778 \\
\hline
\end{tabular}

\begin{tabular}{lcrcccc} 
ANOVA & \multicolumn{1}{l}{ MS } & $F$ & $P$-value & $F$ crit \\
\hline Source of Variation & \multicolumn{1}{c}{$S S$} & \multicolumn{1}{c}{$d f$} & $M S$ & & \\
\hline Between Groups & 176,08 & 3 & 58,69444444 & 13,72077922 & $6,3535 \mathrm{E}-06$ & 2,901119584 \\
Within Groups & 136,89 & 32 & 4,277777778 & & & \\
Total & 312,97 & 35 & & & & \\
\hline
\end{tabular}

Source: Own projection, usind Excel-Microsoft Office

The null hypothesis assumes that there are no significant differences between Big 4 companies

Alternative hypothesis contradicts the null hypothesis

$\mathrm{F}$ calculated $>\mathrm{F}$ tabelated results that there are significant differences between the companies in 
Big 4 (the null hypothesis is rejected, the alternative hypothesis is accepted)

Table 4. Model validity (ANOVA: Single Factor for the year 2018)

Anova: Single Factor for the 2018

SUMMARY

\begin{tabular}{lrcrc}
\hline \multicolumn{1}{c}{ Groups } & Count & Sum & Average & Variance \\
\hline Deloitte & 3 & $1,11 \mathrm{E}+08$ & 37098551 & $2,99077 \mathrm{E}+15$ \\
KPMG & 3 & 56380062 & 18793354 & $8,27254 \mathrm{E}+14$ \\
Ernst\&Young & 3 & $1,56 \mathrm{E}+08$ & 51938638 & $6,56529 \mathrm{E}+15$ \\
PRICEWATERHOUSECOOPERS & 3 & $1,09 \mathrm{E}+08$ & 36279359,67 & $3,48778 \mathrm{E}+15$ \\
\hline
\end{tabular}

\begin{tabular}{|c|c|c|c|c|c|c|}
\hline Source of Variation & $S S$ & $d f$ & $M S$ & $F$ & $P$-value & F crit \\
\hline Between Groups & $2 \mathrm{E}+15$ & 3 & $5,51391 \mathrm{E}+14$ & 0,159004203 & 0,9209222 & 4,066180551 \\
\hline Within Groups & $3 E+16$ & 8 & $3,46777 \mathrm{E}+15$ & & & \\
\hline Total & $3 E+16$ & 11 & & & & \\
\hline
\end{tabular}

Source: Own projection, usind Excel-Microsoft Office

The same thing is demonstrated by analyzing the three indicators that show the success rate of companies providing accounting services.

\section{Conclusion}

Thus, it could be confirmed that financial reporting according to International Financial Reporting Standards has increased the number of companies audited by Big 4, even though these audit fees have recorded high values. Moreover, the effect is positive for all companies of different sizes, but the share of expenses is lower for larger companies.

This paper follows to establish the link between some important macroeconomic indicators and audit fees index for the mentioned period, which tried to find out which variables affect this index. A factor analysis was used in 22 countries from Europe. The strongest link for Europe is between CA and Big 4 companies and the link is direct. The link is moderate, as Profit/Loss increases, the number of Big 4 increases too and the level of audit fees increases also.

It can conclude that the growth of audit fees for Europe is explained by the the growth of the companies audited by Big 4. Further research aims to extend the sample globally, but also to include other variables. In addition, depending on the possibilities of accessing the specific data series, the study can also be applied for another romanian regions.

\section{References}

Adams M., (1994),"Agency Theory and the internal Audit", Managerial Auditing Journal, Vol. 9, pp. 8-12.

Alzoubi E., 2016, “Audit quality and earnings management: evidence from Jordan”, Journal of Applied Accounting Research, Volume 16, No. 2, pp. 170-189.

Asthana S., si Boone J., (2012), "Abnormal audit fee and audit quality", Auditing: A Journal of practice \& Theory, Vol.13, No. 3, pp.1-22.

Baccini, A., Besse, P.: Data mining I Exploration Statistique. Universite Paul Sabatie Press, Toulouse (2005).

Ball R., (2014), "IFRS pros and cons for investors", Accounting and Business Research", pp. 527.

Boone J., Khurana I. si Raman K., (2010), "Do the Big 4 and second tier firms provide audits of similar quality", Journal of Accounting and Public Policy, Vol.29, No.4, pp.330-352. 
Brown P., Preiato J., (2013), "Mandatory Adoption of IFRS and Analysts' Forecasts: How Much Does Enforcement Matter?", SSRN Electronic Journal, Vol. 10, pp. 187-193.

Choi J., Kim J. si Zang Y., (2010), “Do abnormally high audit fees impair audit quality?", Auditing: A Journal of Practice \& Theory, Vol.29, No.3, pp.297-322.

DeGeorge E., Ferguson C. \& Nasser S., (2013),"How Much Does IFRS Cost? IFRS Adoption and Audit Fees", American Accounting Association, Vol. 88, pp. 429-462.

Diehl X.A, (2010), "The relationship between IFRS Implementation and Audit Tax, and other auditor fees", Journal of Finance Economics, Vol. 37, pp.96-101.

Eshleman D. si Guo P., (2014), "Do big 4 auditors provide higher audit quality after controlling for the endogenous choice of auditor?", Auditting: A Journal of Practices and Theory, Vol.33, No.4, pp. 197-219.

Fleischer R and Goettsche M., (2012), "Size effects and audit pricing: Evidence from Germany", Journal of International Accounting, Auditing and Taxation, Volume 21, pp.156-168.

Fox, J.: Applied regression analysis, linear models, and related methods. CA. Sage Publications, Thousand Oaks (1997).

Fung et al., (2012), "City-Level Auditor Industry Specialization, Economies of Scale, and Audit Pricing", The Accounting Review, Volume 87, No. 4, pp. 1281- 1307.

Getz, K.A. and Volkema, R.J.: Culture, Perceived Corruption, and Economics A Model of Predictors and Outcomes. Business \& Society, 40(1), pp. 7-30 (2001).

Habib, M. and Zurawicki, L.: Corruption and Foreign Direct Investment. Journal of International Business Studies, 33 (2), pp. 291-307 (2002).

Hamberg M., Paananen M. si Novak J., (2011), "The adoption of IFRS 3: The effects of managerial discretion and stock market reactions", European Accounting Review, Vol. 20, No.2, pp.26-288.

Hayes, R., Dassen Roger, Schilder, A., Wallage, P., (2005)“Principles of Auditing. An Introduction to International Standards of Auditing", second edition, Ed. Pearson Education, pp. 44-47.

Hudson J., (2014), "Agensy and IFRS Implementation: The relationship between Primary Participants", Kwansei Gakuin University Repository, Vol, 8, pp. 61-79.

Jaba, E.: Statistica, 2nd edn. Editura Economică, București (2002).

Janowski T., (2017), "Top six audit firms push for global IFRS adoption”, Discover Thomson Reuters, https://www.reuters.com/article/financial-accounting-six/top-six-auditfirms-push-for-global-ifrs-adoption-idUSN1440000020080115

Jeanjean,T.,Stolowy,H. ,2008.Do accounting standards matter?An exploratory analysis of earnings management before and after IFRS adoption. Journal of Accounting and Public Policy Vol. 27, pp.480-494.

Jensen M.\& Meckling W., (1976), "Theory of the Firm: Managerial Behavior, Agency Costs and Ownership structure”, Journal of Financial Economics, Vol. 3, pp. 305-360.

Jung J., 2015,"The association between abnormal audit fees and audit quality after IFRS adoption: Evidence from Korea", International Journal of Accounting\& Information Management, Vol. 24, pp.2-8.

Klarskov Jeppesen, K. (1998) „Reinventing auditing, redefining consulting and independence”, European Accounting Review, vol. 7, no. 3, pp. 517-539

Lambsdorff, J.G.: The Methodology of the Corruption Perceptions Index. Transparency International (TI) and University of Passau (2006).

Leventis S., Weetman P. \&Caramanis C. (2011)“Agency costs and product market competition: The case of Audit pricing in Greece", The British Accounting Review, Vol. 43., pp. 112119.

Lopez D. si Peters G., (2012), "The effect of workload compression on audit quality”, Auditing: A Journal of Practice \& Theory, Vol.31, No.4, pp.139-165.

Melgar, N., Rossi, M., Smith, T.W.: The Perception of Corruption. International Journal of Public Opinion Research, 22(1), pp.120-131 (2010).

Mohammad A., (2009), " Factors associated wih the use of and the compliance with the IIA Standards: A study of Anglo-Culture CAEs", International Journal of Accounting, Vol. 
13 , pp 22-26.

Park J., (2012), "Effects of abnormal audit fee on real earning management", Journal of Taxation and Accounting, Vol.13, No.3, pp.83-112.

Pârțachi, I., Diaconu, A., Dinu, A. M., Păunescu, C.: Noţiuni generale privind regresia liniară simplă. Revista de Statistică, Supliment 3,128-132 (2012).

Pintilescu, C.: Multivariate statistic analysis. The University “Al. I Cuza" Pres, Iasi (2007).

Podobnik, B., Shao, J., Njavro, D., Ivanov, P.C., Stanley, H.E.: Influence of corruption on economic growth rate and foreign investment. The European Physical Journal B, 63(4), pp. 547-550 (2008).

Reichelt K. și Wang D., (2010), "National and office-specific measures of auditor industry expertise and effects and audit quality", Journal of Accounting Research, Vol.48, No.3, pp. 647-686.

Robertson, C.J. and Watson, A.: Corruption and change: the impact of foreign direct investment. Strategic Management Journal, 25(4), pp. 385-396 (2004).

Simunic D., 1980, "The Pricing of Audit Services: Theory and Evidence", Journal of Accounting Research, Vol. 18, No. 1 (Spring, 1980), pp. 161-190.

Tokar, M. (2005) "Convergence and the implementation of a single set of global standards: the real-life challenge", Accounting in Europe, Vol. 2, No. 1, pp. 47-68

Wallace, W. (1984), "Internal auditors can cut outside CPA costs", Harvard Business Review , pp. $16-20$

Watson M. \& MacKay J., (2003), “Audit for the environment”,Managerial Auditing Journal, Vol. 18, pp. 625-630.

Zeff, S. (2003a), "How the US accounting profession got where it is today: part I", Accounting Horizons", Vol. 17 No. 3, pp. 189-205. 